\title{
Ethnopharmacological Uses of Embelia ribes Burm. F. - A Review
}

\author{
K. Souravi and P. E. Rajasekharan \\ Division of Plant Genetic Resources, Indian Institute of Horticultural Research, Bangalore.
}

\begin{abstract}
Embelia ribes Burm.f. is a threatened medicinal plant, studied extensively for its rich medicinal properties. It has been used in ayurvedic formulations from the ancient times and in the recent past a surge of research on this particular medicinal plant species has been undertaken. This particular species is found to attribute to a number of medicinal properties such as antidiabetic, anticancer, antimicrobial, antitumor, antifertility activity and many more. Hence this highly comprehensive review has been under taken to highlight the areas of research where in this particular species is extensively studied and the current status of this important threatened medicinal plant.
\end{abstract}

Key Words: Embelia ribes, Ethonopharmacology, Medicinal uses, Threatened, Embelin, Phytochemistry.

\section{Introduction}

Herbal medicine is still the mainstay of about $75-80 \%$ of the world population, particularly in the developing countries, for primary health care because of better cultural acceptability, compatibility with the human body and lesser side effects (1). Keeping note of which many of the drugs today are being developed from plants that are used in traditional systems of medicines such as Sidda or Ayurveda. The references of which can be found in ancient Vedas and sacred texts such as the Muslim Materia Medica, the text of Jami of Ibn Baiar (1248 A.D.), which lists more than 2,000 substances; including many plant products (Ackerknecht, 1973), the principal Ayurvedic text on internal medicine, the Charka Samhita, which describes 582 herbs (Majno, 1975) or the main text on surgery, the Sushruta Samhita, which lists some 600 herbal remedies. As most of the plants are documented for their medicinal properties, in various traditional systems, they are more likely to contain active chemical compounds thereby proving particularly successful in discovery of new and more effective drugs

Embelia ribes Burm. f., mentioned since the ancient times, in the form of the drug 'Vidanga' or 'Baibidanga' has been an important ingredient in a number of ayurvedic formulations (2). Vidanga has found a mention in all the three ancient Indian ayurvedic texts namely Charakh Samhita, Sushurta Samhita and Ashtanga hridayam. Besides Ayurveda, Vidanga is reported to be used in Unani (Baobarang), Siddha (Vaivilangam), Folk, Tibetan (Byi dan ga) and Homopathic (Embelia ribes) systems of medicines as well. Many scholars of Ayurveda and botany have correlated Vidanga to the plant Embelia ribes Burm. f. Vidanga was included as official drug in the Indian Pharmacopoeia in the year 1966 and the botanical origin was described as fruits of E.ribes only. Since then, it is widely accepted that the botanical source of the drug 'Vidanga' is the dried berries of fruits of E. ribes belonging to family Myrsinaceae(3). Although E.ribes have been used in other medicinal systems such as Unani, Homopathic etc, the major system employing E.ribes and its constituents is the ancient Ayurveda as shown in Fig 1.

Figure 1: Percentage of E.ribes used in Ayurveda and other systems.

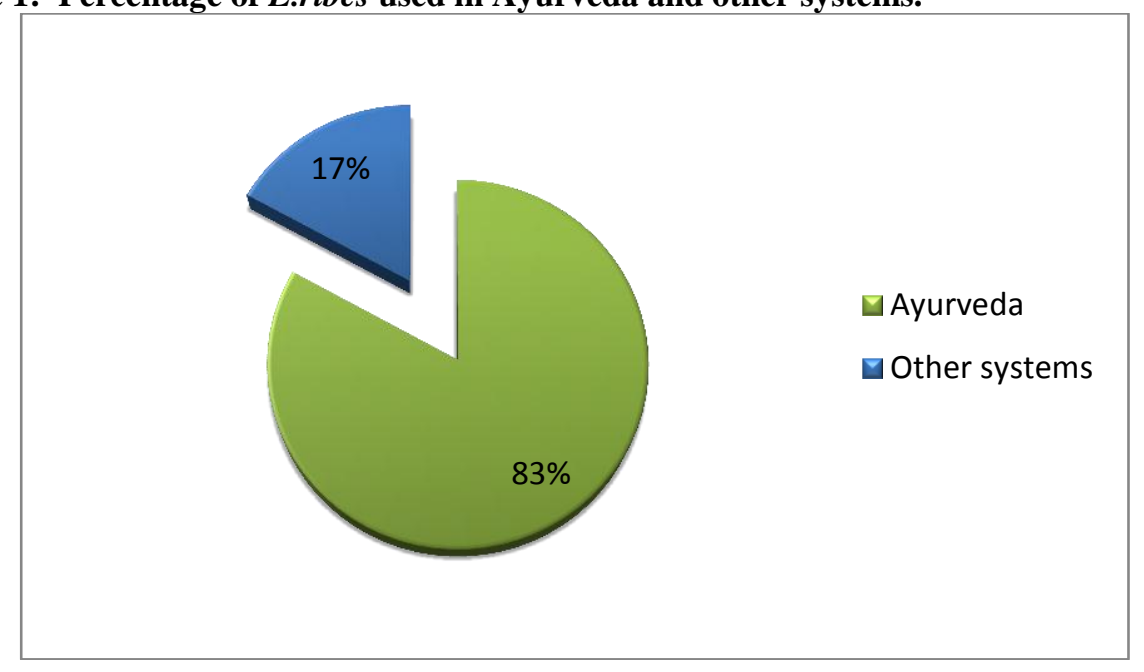




\section{II. ayurvedic properties}

E. ribes is found attributing to 6 different of ayurvedic properties $(4,5)$, which has formed as the basis for many ayurvedic formulations as shown in TABLE $\mathbf{1}$.

\begin{tabular}{|l|}
\hline Rasa (taste) - Katu (pungent), Kashaya (Astringent) \\
\hline Guna (qualities)- Laghu (lightness), Ruksa (dryness),Teekshna (piercing, strong) \\
\hline Virya- Ushna - hot potency \\
\hline Vipaka- Katu - Undergoes pungent taste conversion after digestion. \\
\hline Prabhava - Special effect - Krumighna - relieves worm infestation. \\
\hline Tridosha - Because of hot potency, it balances Kapha and Vata Doshas. \\
\hline
\end{tabular}

\section{Ayurvedic Formulations}

E. ribes has also been used in about 75 different ayurvedic formulations (6) some of the commonly used formulations are given in TABLE 2.

\begin{tabular}{|l|l|}
\hline \multicolumn{1}{|c|}{ Formulation } & \multicolumn{1}{c|}{ Uses } \\
\hline Sara & Eases the movement of contents in the intestinal track \\
\hline Krumihara & Useful in worm infestation \\
\hline Krumikushta & Useful in infective skin diseases \\
\hline Pramehahara & Useful in diabetes \\
\hline Shirorogahara & Useful in headache \\
\hline Vahnikara & Improves appetite \\
\hline Shulahara & Useful in abdominal colic pain \\
\hline Adhmanahara & Relieves bloating \\
\hline Udarahara & Useful in abdominal distension, ascites \\
\hline Shleshma Krumihara & Useful in worm infestation of Kapha origin \\
\hline Vatahara & Balances vata \\
\hline Artinut & Relieves pain \\
\hline Agnimandyahara & Relieves indigestion, weak digestion \\
\hline Aruchihara & Relieves anorexia \\
\hline Vibhrantihara & Relieves dizziness \\
\hline Shirovirechana & Nasal drops \\
\hline &
\end{tabular}

\section{Traditional Uses}

E.ribes has been used traditionally in various health care purposes for over 5000 years (7). The traditional uses are as follows:

It detoxifies blood, hence useful in wide range of skin diseases.

It has contraceptive effect, along with Pippali (long pepper)

It improves skin complexion and also used for rejuvenation purpose.

Its water decoction is used for oil pulling to relieve dental caries and bad breath

In skin diseases, it is used both orally and externally in the form of paste.

It has mild diuretic action.

It is useful against vomiting, bloating, indigestion, gastritis and constipation.

It is widely used in weight loss treatment

\section{Phytochemistry}

The ripe fruits of E. ribes are the most commercially important part of the plant; as they have been found to contain the active compound namely Embelin (8).<smiles>CCCCC1=C(O)C(=O)C=C(O)C1=O</smiles>

Embelin 
Further phytochemical investigation resulted in three new compounds namely embelinol, embeliaribyl ester and embeliol (9). Also another compound namely Vilangin was isolated from the ripe fruit berries (10).

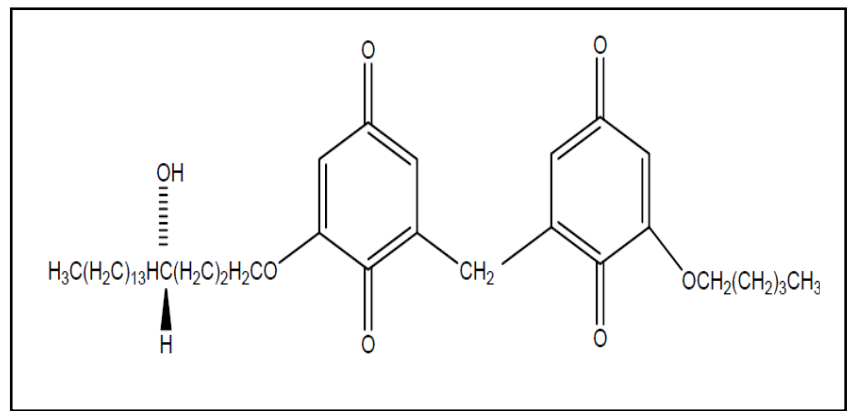

Embeliaribvl ester

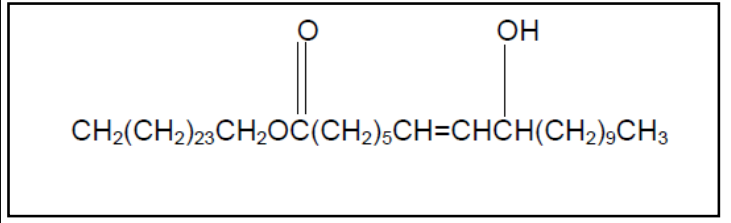

Embelinol

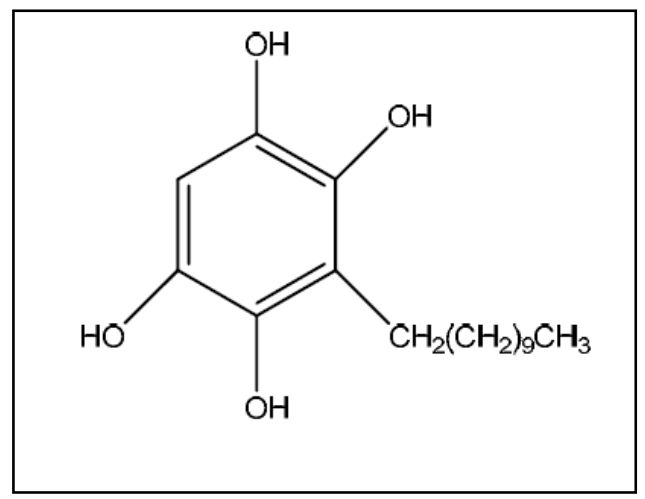

Embeliol

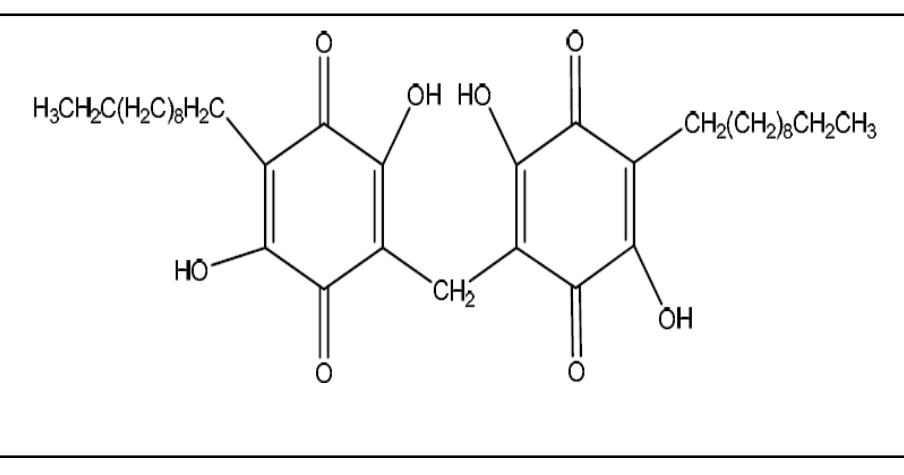

Vilangin

Yet another compound discovered from E.ribes during the late nineties is the Potassium embelate (11). The plant has also been found to contain quercitol and fatty ingredients, an alkaloid, christembine, a resinoid, tannins and minute quantities of a volatile oil (12). It has also been studied that the seeds of E.ribes showed the presence of $\mathrm{Cr}, \mathrm{K}, \mathrm{Ca}, \mathrm{Cu}, \mathrm{Zn}$ and $\mathrm{Mn}$ along with high carbohydrates (13).

Stress degradation studies on embelin were carried out and it was found that embelin was susceptible to oxidative, acid and to lesser extent thermal degradation. It was observed that embelin etherifies when stored in alcohol (methanol or ethanol) in presence of acid to form corresponding ethers of embelin. The relevance of these studies in predicting the stability of embelin in Ayurvedic formulations is that they are known to contain self-generated alcohol which under acidic conditions may undergo etherification to form corresponding ether of embelin (14).

\section{Pharmacology}

Following the folk and traditional uses of E.ribes, it is being investigated scientifically to confirm its potentiality to cure and treat various diseases (15). Some of the reported pharmacological activates of E.ribes are mentioned in TABLE 3.

\begin{tabular}{|c|c|c|c|}
\hline Activity/ Disease & Tested Organism & Extract/ deravatives/Salts & References \\
\hline \multirow[t]{3}{*}{ Analgesic activity } & \multirow[t]{3}{*}{ Rat } & Embelin & [16] \\
\hline & & Embelin- disalts & [17] \\
\hline & & Potassium embelate & [18] \\
\hline Anthelmintic activity & $\begin{array}{l}\text { Pheritima posthuma, Haemonchus } \\
\text { contortus, Taenia canina, } \\
\text { Phamphistomum cervi }\end{array}$ & Aqueous and alcoholic extracts & {$[19,20,21,22,23]$} \\
\hline Antianxiety activity & Rat & Embelin & {$[24,25,26]$} \\
\hline \multirow[t]{2}{*}{ Antibacterial activity } & $\begin{array}{l}\text { Bacilus subtilis, Staphylococcus } \\
\text { aureus , Escherichia coli, } \\
\text { Pseudomonas aeruginosa }\end{array}$ & Aqueous and ethonolic extracts & {$[27,28]$} \\
\hline & $\begin{array}{l}\text { Bacillus Polymyxa and Proteus } \\
\text { vulgaris }\end{array}$ & aryl substituted benzoxadiazine & [29] \\
\hline Antinematodal activity & Goat & Seed oil & {$[30]$} \\
\hline Ascaricidal properties & Taenia and Hookworm & Seed oil & {$[31]$} \\
\hline
\end{tabular}


Ethnopharmacological Uses of Embelia ribes Burm. F. - A Review

\begin{tabular}{|c|c|c|c|}
\hline \multirow[t]{7}{*}{ Anticancer activity } & fibrosarcoma cell line & Embelin & {$[32]$} \\
\hline & HeLa cell line & $\begin{array}{l}\text { 5-O-ethylembelin, 5-O- } \\
\text { methylembelin(deravatives) }\end{array}$ & {$[33,34]$} \\
\hline & PC-3 xenograft model & Embelin & [35] \\
\hline & HepG2 cells & Embelin & {$[36]$} \\
\hline & Wistar rats & Embelin & [37] \\
\hline & MCF-7 cancer cells & Embelin & {$[38]$} \\
\hline & $\begin{array}{l}\text { Human leukaemic cells (K562) and } \\
\text { Dalton's Lymphoma ascites cells } \\
\text { (DLA) }\end{array}$ & Embelin & [39] \\
\hline $\begin{array}{l}\text { osteoporosis and cancer- } \\
\text { linked bone loss }\end{array}$ & Breast cancer cells & Embelin & {$[40,41]$} \\
\hline Anticonvulsant activity & Rat & Embelin & {$[42]$} \\
\hline Antidepressant activity & Mice & Embelin & [43] \\
\hline \multirow[t]{4}{*}{ Antifertility activity } & male albino rats & Embelin & {$[44,45,46,47,48]$} \\
\hline & male bonnet monkeys & E.ribes berries & [49] \\
\hline & rabbits & Embelin & {$[50]$} \\
\hline & female Sprague-Dawley rats & Embelin & {$[51,52]$} \\
\hline \multirow[t]{2}{*}{ Antifungal activity } & $\begin{array}{l}\text { Colletotricum } \\
\text { crassipes, Cladosporium, Armillaria } \\
\text { mellea, Colletotricum capsici, } \\
\text { Aspergillus niger, Rhizopus oryzae, } \\
\text { Aspergillus terreus and Candida }\end{array}$ & Seed Extract & {$[53]$} \\
\hline & Candida species & Embelin & {$[54,55,56]$} \\
\hline Antigenotoxicity activity & mouse bone marrow cells & Embelin & [57] \\
\hline Antihistamic activity & guinea pigs & Embelin & {$[58]$} \\
\hline Antimitotic activity & $\begin{array}{l}\text { Bengal gram seeds and germinating } \\
\text { Onions }\end{array}$ & $\begin{array}{l}\text { 2-hydroxy-5-substituted-3- } \\
\text { undecylcyclohexa-2,5-diene-1,4-diones } \\
\text { (deravatives) }\end{array}$ & [59] \\
\hline \multirow{3}{*}{$\begin{array}{l}\text { Antioxidant and } \\
\text { Neuroprotective activity }\end{array}$} & Rat & Embelin & {$[60,61]$} \\
\hline & Male Wistar albino rats & ethonolic extracts & {$[62,63]$} \\
\hline & peripheral blood human lymphocytes & Embelin & {$[64]$} \\
\hline Cardioprotective activity & Rat & Aqueous and alcoholic extracts & {$[65,66,67]$} \\
\hline Cosmetic agent & - & Embelin & [68] \\
\hline Wound healing activity & Swiss Albino Rats & ethonolic extracts, Embelin & {$[69,70]$} \\
\hline Nephroprotective activity & albino rats & ethonolic extract, Embelin & {$[71,72]$} \\
\hline Antidiabetic activity & Wistar rats & ethanolic extract, Embelin & {$[73,74,75,76,77]$} \\
\hline
\end{tabular}

It has also been analysed that although research has been focussed to study the various activities of E.ribes, major part of the studies are focussed in the fields of cancer, diabetes and infertility as E.ribes has proved to be a very good candidate for antitumor, antiglycemic and antifertility activity (Fig 2). Further analysis showed that a major number of these studies are conducted either using aqueous alcoholic extracts or by employing the purified embelin compound (Fig 3). Although there have been studies employing various derivatives of embelin compound. 
Figure.2:

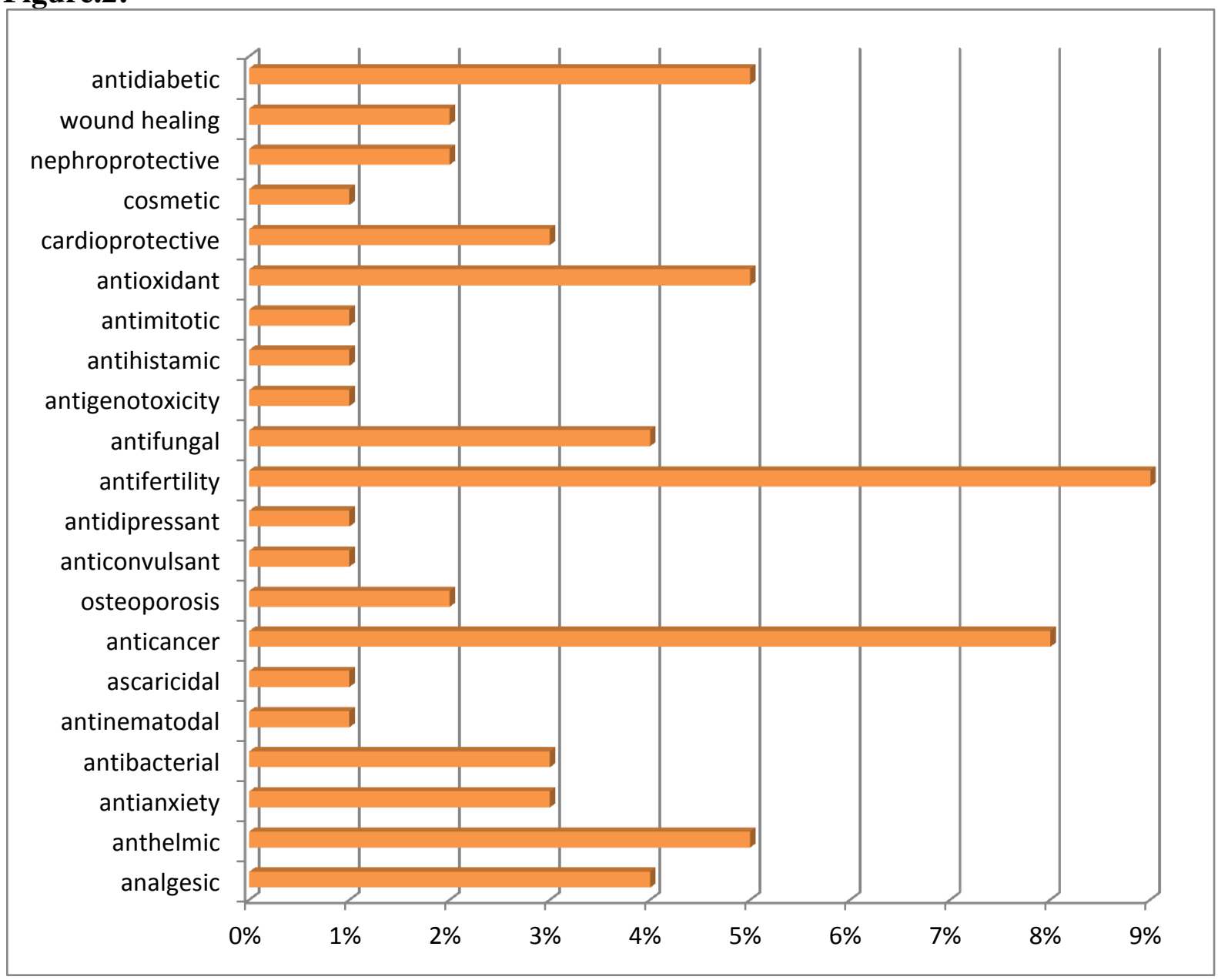

Figure 3:

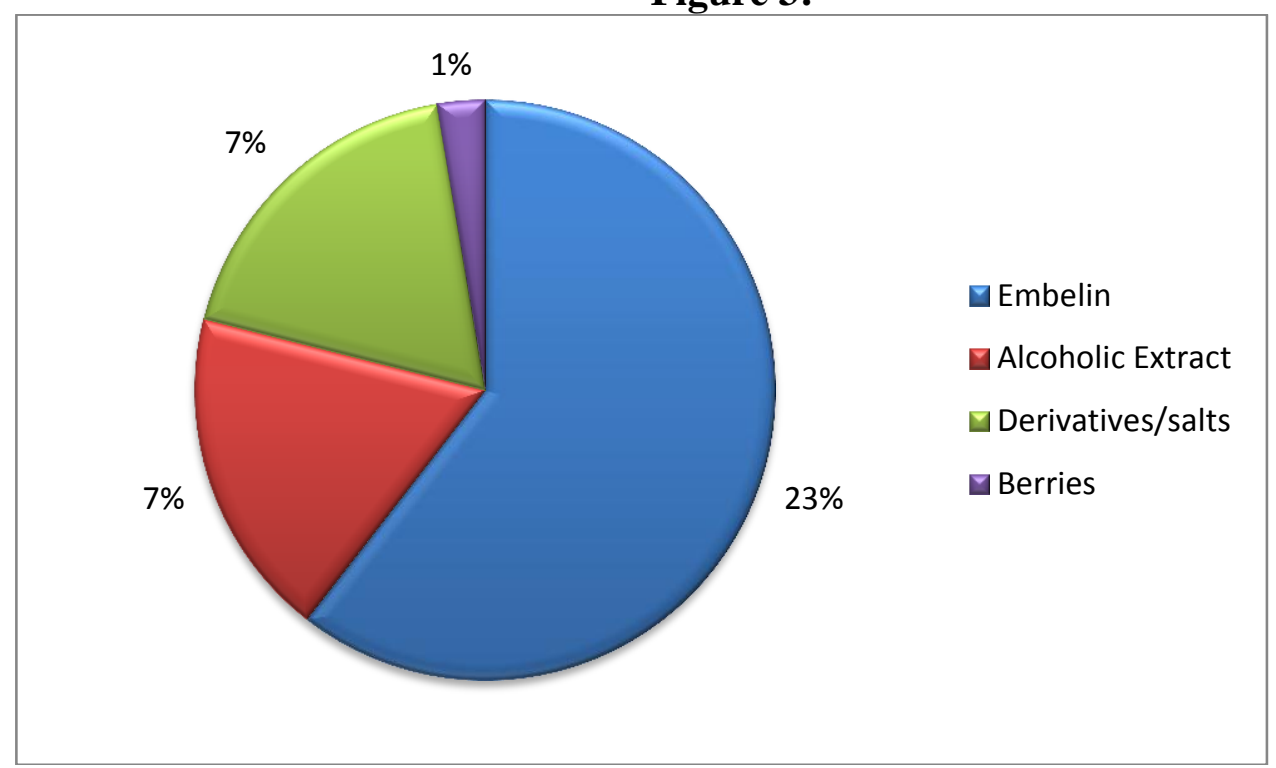

\section{Discussion And Conclusion}

Plants have been a source of medicine from time immemorial. Though health management systems have two distinct areas namely traditional system of medicine and modern system of medicine, their common roots are medicinal plants (78). It is therefore very important to have proper documentation of the medicinal plants, their sources, effects and uses. Thus a detailed and systematic ethnomedicinal study is required for 
identification, cataloguing and documentation of plants, which will help promote traditional knowledge of herbal medicinal plants, further fuelling research and identification of newer drugs in the field of medicinal plants.

It is seen from the literature that E.ribes is a very important medicinal plant for its extensive medicinal properties. The plants shows a number of pharmacological activites such as wound healing, antitumor, cardiovascular, hypoglycemic, antioxidant, antimicrobial, antidiabetic and antifertlity. Many other traditionally uses are also reported such as blood purifier, cosmetic agent, oil pulling and oral contraceptive which are still being studied till today and further research is still in progress. Thus it can be concluded that E.ribes is a promising target to generate newer and novel drugs.

\section{References}

[1]. Kamboj V P. Herbal medicine. Current Science. 200078(1):35-39

[2]. Warrier P K, Nambiar V P K, Ganapathy P M. Some important medicinal plants of western Ghats, India: A Profile. International Development Research Centre (IDRC), Canada. 2001.139-156.

[3]. Ved D K, Archna Singh. Identity of vidanga - a plant drug in trade. Newsletter-Medicinal plants of conservation concern. AprilJune 2006.

[4]. Syed Asadulla, Ramandang, Rajasekharan. Pharmacognosy of Embelia ribes Burm.f. International Journal of Research in Pharmacy and Chemistry. 2011. 1 (4):1236-1251

[5]. Anonymous. Compendium of medicinal plants. National Institute of Industrial Research, Kamala Nagar, New Delhi, India. 2005. 110-113.

[6]. Anonymous. The Ayurvedic Pharmacopoeia of India. Govt of India, Ministry of Health and Family Welfare, Dept of Aysuh. 2001. 1(1): $163-165$.

[7]. Vidanga - Embelia ribes - Benefits, Usage, Dose, Side Effects. http://easyayurveda.com/2013/09/23/vidanga-embelia-ribesbenefits-usage-dose-side-effects/ [Access Date: 3.11.2013]

[8]. Hao K, Ali M, Siddiqui A W. New compounds from the seeds of Embelia ribes Burm. Pharmazie. 2005. 60(1): 69-71.

[9]. Biradar Y S. Phytochemical and pharmacological review of selected plants- Adhatoda Zeylancia Nees and Embelia ribes Burm.f. Phytochemical and Pharmacological Review of Adhatoda zeylanica and Embelia ribes. 2010.4:55-68.

[10]. Venkateswarlu V , Bheemasankara Rao Ch. Vilangin - A new constituent of Embelia ribes and E. Robusta. Current Science. 1961. 30: 259 .

[11]. Johri R K, Dhar S K, Pahwa G S, Sharma S C, Kaul J L, Zutshi U. Toxicity studies with potassium embelate, a new analgesic compound. Indian Journal of Experimental Biology. 1990. 28: 213-217.

[12]. Ibrahim Khan M, Afzal Ahmed, Akram M, Mohiuddin E, Khan Usmanghani, Sultan Ayaz, Ali Shah S M, Asif M, Ghazala Shaheen, Khalil Ahmed, Riaz Ur Rehman. Monograph of Embelia ribes. African Journal of Plant Science.2010. 4(12): 503-505.

[13]. Indryan A K, Sharma, Sudeep Durgapal, Deepak Kumar, Neeraj , kumar Manoj. Determination of nutritive value and analysis of mineral elements for some medicinally valued plants from Uttaranchal. Current science. 2005. 89 (7): 1252-1255.

[14]. Galvina Ferreira , Laddha K S. Stress Degradation Studies on Embelin. Indian J. Pharm. Sci. 2013. 75(2): $246-250$.

[15]. Harish G U, Vijay Danapur, Renuka Jain, Villoo Morawala Patell. Endangered Medicinal Plant Embelia ribes Burm.f.-A review. Pharmacognosy Journal. 2012. 4(27): 6-19.

[16]. Atal C K, Siddiqui M A, Zutshi U, Amla V, Johri R K, Rao P G, Kour S. Non-narcotic orally effective, centrally acting analgesic from an Ayurvedic drug. J.Ethnopharmacol. 1984. 11(3): 309-17.

[17]. Gupta O P, Ali M M, Ray Ghatak B J, Atal C K. Some pharmacological investigations of embelin and its semisynthetic derivatives. Indian J Physiol Pharmacol.1977. 21(1):31-39.

[18]. Zutshi U, Johri R K, Atal C K. Possible interaction of potassium embelate, a putative analgesic agent, with opiate receptors. Indian Journal of Experimental Biology. 1989. 27(7):656-657.

[19]. Jalalpure S S, Alagawadi K R, Mahajanashetti C S, Shah B N, Salahuddin, Singh V, Patil J K. In vitro anthelmintic property of various seed oils against Pheritima posthuma. Indian J.Pharm. Sci. 2007. 69: 158-160.

[20]. Khare C P. Indian Herbal Remedies. Rational western therapy, Ayurvedic and other traditional usage. Springer. 2004. 200-201.

[21]. Sajith Mohandas, Sreekumar T R, Vishnu Prakash. Anthelmintic Activity of Vidangadi Churna. Asian journal of Pharmaceutical and clinical Research. 2013. 6(3):94-95.

[22]. Hördegen P, Cabaret J, Hertzberg H, Langhans W, Maurer V. In vitro screening of six anthelmintic plant products against larval Haemonchus contortus with a modified methyl-thiazolyl-tetrazolium reduction assay. Journal of Ethnopharmacology.2006. (108)1: 85-89.

[23]. Neogi N C, Baliga P A C, Srivastva R K. Anthelmintic activity of some indigenous drugs. Indian J. Pharm. 1964. 26: 37-39.

[24]. Antianxity activity of Embelin isolated from Embelia ribes. http://www.pharmatutor.org/articles/antianxiety-activity-embelinisolated-embelia-ribes [Access Date: 4.11.2013].

[25]. Ghaisas M M, Wadikar A D, Gulati T B, Limaye R P. Anxiolytic Effect of a Methanolic Extract of the Embelia ribes Burm F. in Mice. Research Journal of Pharmacy and Technology. 2010. (3) 4: 1136 -1139.

[26]. Muhammad Afzal, Gaurav Gupta, Imran Kazmi, Mahfoozur Rahman, Gaurav Upadhyay, Kamran Ahmad, Faisal Imam, Mohammad Pravez, Firoz Anwar. Evaluation of anxiolytic activity of embelin isolated from Embelia ribes. Biomedicine and Aging Pathology.2012. 2(2): 45-47.

[27]. Mohammad Alam Khan, Menda Akkulu Naidu, Zafar Akbar. In Vitro Antimicrobial Activity of Fruits Extract of Embelia ribes Burm. International Journal of Pharmaceutical \& Biological Archives. 2010. 1(3): $267-270$.

[28]. Radhakrishnan N, Gnanamani A, Mandal A B. A potential antibacterial agent Embelin, a natural benzoquinone extracted from Embelia ribes. Biology and Medicine. 2011.3 (2): 1-7.

[29]. Brahmeshwari G, Kumaraswamy G. Anti bacterial activity of benzoxadiazines derived from Embelin. IJPBS.2012. 2( 2): $284-287$.

[30]. Javed I, Akhtar M S. Screening of Veronica anthelmintica seed and Embella ribes fruit mixed in equal parts against gastrointestinal nematodes. Pak. J. Pharm. Sci. 1990. 3(2): 69-74.

[31]. Garg L C, Mehta R K. In vitro studies on anthelmintic activity of Butea frondosa and Embelia ribes. Journal Vet. Husbandry Research. (India) 1958.(3) 1: 28-31.

[32]. Chitra M, Sukumar E, Shyamala Devi C S. $\left[{ }^{3} \mathrm{H}\right]$-Thymidine Uptake and Lipid Peroxidation by Tumor cells on Embelin Treatment: An in vitro study. Oncology. 1995. 52: 66-68. 
[33]. Minjuan Xu, Jingrong Cui, Hongzheng Fu, Peter Proksch, Wenhan Lin, Min Li. Embelin Derivatives and Their Anticancer Activity through Microtubule Disassembly. Planta Med. 2005. 71 (10): 944 -948.

[34]. Xu M, Cui J, Fu H, Proksch P, Lin W, Li M. Embelin derivatives and their anticancer activity through microtubule disassembly. Planta Medica. 2005. 71(10): 944-948.

[35]. Dai Y, Desano J, Qu Y, Tang W, Meng Y, Lawrence T S, Xu L. Natural IAP inhibitor Embelin enhances therapeutic efficacy of ionizing radiation in prostate cancer. Am. J. Cancer Res. 2011. 1(2): 128-43.

[36]. Asaf Taghiyev, Deguang Sun, Zhen Ming Gao, Rui Liang,Liming Wang. Embelin-induced apoptosis of HepG2 human hepatocellular carcinoma cells and blockade of HepG2 cells in the G2/M phase via the mitochondrial pathway. Experimental and Therapeutic Medicine. 2012. 4: 649-654.

[37]. Sreepriya M, Geetha Bali. Chemopreventive effects of embelin and curcumin against $N$-nitrosodiethylamine/ phenobarbitalinduced hepatocarcinogenesis in Wistar rats. Fitoterapia. 2005. Vol 76, Issue 6, Pages 549-555.

[38]. Yang Li, Dalei Li, Shengguang Yuan, Zhenran Wang, Fang Tang, Rongrong Nie, Jun Weng, Lina Ma and Bo Tang. Embelininduced MCF-7 breast cancer cell apoptosis and blockade of MCF-7 cells in the G2/M phasevia the mitochondrial pathway. Oncology Letters. 2013. 5: 1005-1009.

[39]. Beena Joya, Lakshmi S. Antiproliferative Properties of Embelia Ribes. The Open Process Chemistry Journal. 2010. 3, 17-22.

[40]. Reuter S, Prasad S, Phromnoi K, Kannappan R, Yadav V R, Aggarwal B B. Embelin suppresses osteoclastogenesis induced by

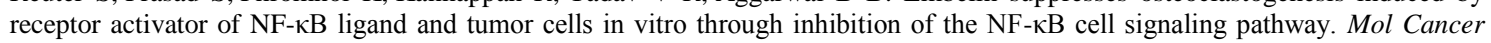
Res. 2010. 8(10): 1425-36.

[41]. Kwang Seok Ahn, Gautam Sethi, Bharat B. Aggarwal. Embelin, an Inhibitor of X Chromosome-Linked Inhibitor-of-Apoptosis Protein, Blocks Nuclear Factor-B (NF-B) Signaling Pathway Leading to Suppression of NF-B-Regulated Antiapoptotic and Metastatic Gene Products. Mol Pharmacol. 2007. 71: 209-219.

[42]. Mahendran S, Thippeswamy B S, Veerapur V P, Badami S. Anticonvulsant activity of embelin isolated from Embelia ribes. Phytomedicine. 2011. 15: 18(2-3):186-8.

[43]. Gaurav Gupta, Imran Kazmi, Muhammad Afzal, Gaurav Upadhyay, Rajnish Singh, Solomon Habtemariam. Antidepressant-like activity of Embelin isolated from Embelia ribes. Phytopharmacology. 2013. 4(1): 87-95.

[44]. Chauhan S, Agrawal S, Mathur R, Gupta R K. Phosphatase activity in testis and prostate of rats treated with embelin and Vinca rosea extract. Experientia.1979.35(9):1183-1185.

[45]. Agrawal S, Chauhan S, Mathur R. Antifertility Effects of Embelin in Male Rats. Andrologia.1986. 18 (2): 125-131.

[46]. Gupta S, Sanyal S N, Kanwar U. Antispermatogenic effect of embelin, a plant benzoquinone, on male albino rats in vivo and in vitro. Contraception. 1989. 39 (3): 307-320.

[47]. Gupta S, Kanwar U., Sanyal S N. Inhibition of reproductive tissue carbohydrate metabolism and reversibility of the effects of embelin, a plant benzoquinone of antifertility potential. Fitoterapia. (61)2:133-143.

[48]. Gupta R S and Rakhi Sharma. A review on medicinal plants exhibiting antifertility activity in males. Natural Product Radiance. 2006.5(5):389-410.

[49]. Simukoko, Humphrey. The effects of embelin (a benzoquinone compound of plant origin) on some reproductive parameters of female sprague-dawley rats. URI: http://erepository.uonbi.ac.ke:8080/xmlui/handle/123456789/19169 [Access date: 4.11.2013].

[50]. Purandare T V, Kholkute S D, Gurjar A, Joshi U M, Dattatreya M B, Sheth A R, Swamy X R, Jayraman S and Munshi R. Semen analysis and hormonal levels in bonnet macaques admistered Embelia ribes berries, an indigenous plant having contraceptive activity, Indian J Exp Biol. 1979. 17: 935-936.

[51]. Nelly N Mungai, Dominic W Makawiti, Victor N Konji. Effect of different doses and routes of administration of embelin on plasma testosterone levels. Phytotherapy Research.1997.11(7): :532-534.

[52]. Wango E O. Anti-fertility effects of embelin in female Sprague-Dawley rats may be due to suppression of ovarian function. Acta Biologica Hungarica. 2005. 56: 1-2.

[53]. Sabitha Rani A, Saritha K, Nagamani V, Sulakshana G. In vitro Evaluation of Antifungal Activity of the Seed Extract of Embelia Ribes. Indian J Pharm Sci.2011. 73(2): 247-249.

[54]. Sanjesh G Rathi, Vaidhun H Bhaskar, Bhuvan P. Raval, Maulik P. Suthar, Paras G. Patel Der. Antifungal Activity of Embelia Ribes. Plant Extracts Pharmacia Letter. 2009. 1(2): 115-120.

[55]. Maulik Suthar, Rakesh Patel, Kalindi Hapani, Avani Patel. Screening of Embelia ribes for Antifungal Activity. International Journal of Pharmaceutical Sciences and Drug Research. 2009. 1(3): 203-206.

[56]. Sanjesh G Rathi, Vaidhun H Bhaskar, Paras G Patel. Antifungal Activity of Embelia Ribes Plant Extracts International Journal on Pharmaceutical and Biological Research. 2010.1(1): 6-10.

[57]. Pankaj Tripathi, Rina Tripathi, Patel R K. Investigation of Antimutagenic Potential of Embelia Ribes Fruit Extract Against Genotoxicity and Oxidative Stress Induced by Cyclophosphamide. Pharmacologyonline. 2010. 3: 867-885.

[58]. Anupama A Suralkar, Jadhav Asha S, Vaidya Gayatri S, Gailwad Kuldeep D. Anthistaminic and bronchodilating activity of fruit berries of Embelia ribes. International Journal of Pharmacy. 2012. 3(10):182-184.

[59]. Kantham Srinivas, Ch. Mahesh, Jagadeesh N. Anti-Mitotic Activity of Embelin Derivatives. International Journal of Phytopharmacology. 2010. 1(2): 97-102.

[60]. Joshi R, Kamat J P, Mukherjee T. Free radical scavenging reactions and antioxidant activity of embelin: biochemical and pulse radiolytic studies. Chem Biol Interact.2007.167(2): 125-134.

[61]. Thippeswamy B S, Nagakannan P, Shivasharan B D, Mahendran S, Veerapur V P, Badami S. Protective effect of embelin from Embelia ribes Burm. against transient global ischemia-induced brain damage in rats. Neurotoxicity Research.2011. 20(4): 379-86.

[62]. Nazam Ansari M, Bhandari U, Islam F, Tripathi C D. Evaluation of antioxidant and neuroprotective effect of ethanolic extract of Embelia ribes Burm in focal cerebral ischemia/reperfusion-induced oxidative stress in rats. Undam Clin Pharmacol.2008. 22(3): 305-314.

[63]. Uma Bhandari, Nazam Ansari M. Protective effect of aqueous extract of Embelia ribes Burm fruits in middle cerebral artery occlusion-induced focal cerebral ischemia in rats. Indian J Pharmacol.2008. 40(5): 215-220.

[64]. Radhakrishnan N, Gnanamani A, Prasad N R, Mandal A B. Inhibition of UVB-induced oxidative damage and apoptotic biochemical changes in human lymphocytes by 2, 5-dihydroxy-3-undecyl-1, 4-benzoquinone (embelin). Int J Radiat Biol.2012. 88(8): 575-82.

[65]. Uma Bhandari, Nazam Ansari M, Islam F. Cardioprotective effect of aqueous extract of Embelia ribes Burm fruits against isoproterenol- induced myocardial infarction in albino rats. Indian Journal of Experimental Biology.2008. 46:35-40.

[66]. Nazam Ansari M, Bhandari U. Effect of an Ethanol Extract of Embelia ribes Fruits on Isoproterenol-Induced Myocardial Infarction in Albino Rats. Pharmacutical Biology.2008.46 (12):928-932. 
[67]. Bhandari, Uma, Ansari, M. Nazam. Ameliorative effect of an ethanol extract of Embelia ribes fruits on isoproterenol-induced cardiotoxicity in diabetic rats. Pharmaceutical Biology (Formerly International Journal of Pharmacognosy).2009. 47(8):669-674

[68]. Radhakrishnan N, Kavitha V, Raja S T K, Gnanamani A, Mandal A B. Embelin-A natural potential cosmetic agent. J. Appl. Cosmetol.2011. 29: 99-107.

[69]. Kumara Swamy H M, Krishna V, Shankaramurthy K, Abdul Rahiman B, Mankani K L, Mahadevan K M, Harish B G, Raja Naika $\mathrm{H}$. Wound healing activity of embelin isolated from the ethanol extract of leaves of Embelia ribes Burm. J.Ethnopharmacol. 2012. 109(3): 529-534.

[70]. Zafar Akbar. Burn Wound Healing Activity of Ethanolic Extract of Embelia ribes Burm. Fruits Alone and in Combination with Silver Sulphadiazine. http/jbiopharm.com/index.php/ajbps/article/view/24/ [Access date: 4.11.13].

[71]. Zafar Akbar, David Banji, Pradip Deshmukh. Prevention of Cisplatin-Induced Nephrotoxicity by Ethanolic Extract of Embelia ribes Fruits and -Tocopherol in Experimental Animals. Journal of Complementary and Integrative Medicine. 7, Issue1.

[72]. Ashish K Sahu, Gautam M K, Pradeep T Deshmukh, Lokendra S Kushwah, Narendra Silawat, Zafar Akbar, Muthu M S. Effect of embelin on lithium-induced nephrogenic diabetes insipidus in albino rats. Asian Pacific Journal of Tropical Disease. 2013. S729S733

[73]. Uma Bhandari, Neeti Jain, and Pillai K K. Further Studies on Antioxidant Potential and Protection of Pancreatic $\beta$-Cells by Embelia ribes in Experimental Diabetes. Experimental Diabetes Research. Volume 2007, Article ID 15803,p.1-6.

[74]. Ashok Purohit, Keshav Bihari Vyas, Surendra Kumar Vyas. Hypoglycaemic activity of Embelia ribes berries (50\% etoh) extract in alloxan induced diabetic rats. Anc Sci Life.2008. 27(4): 41- 4.

[75]. Gandhi G R, Stalin A, Balakrishna K, Ignacimuthu S, Paulraj M G, Vishal R. Insulin sensitization via partial agonism of PPAR $\gamma$ and glucose uptake through translocation and activation of GLUT4 in PI3K/p-Akt signaling pathway by embelin in type 2 diabetic rats. Biochim Biophys Acta. 2013. 1830(1): 2243-55.

[76]. Uma Bhandari, Raman Kanojia, Pillai K K. Effect of Ethanolic Extract of Embelia ribes on Dyslipidemia in Diabetic Rats Int. Jnl. Experimental Diab. Res. 2000. 3: 159-162.

[77]. Jagadeesh M C, Sreepriya M, Geetha Bali, Manjulakumari D. Biochemical studies on the effect of curcumin and embelin during Nnitrosodiethylamine/ phenobarbital induced-hepatocarcinogenesis in wistar rats. African Journal of Biotechnology. 2009.8(18): 4618-4622.

[78]. Mohd. Mazid, Taqi Ahmed Khanb, Firoz Mohammada. Medicinal Plants of Rural India: A Review of Use by Indian Folks. Indo Global Journal of Pharmaceutical Sciences. 2012. 2(3): 286-304. 